\title{
BIODEGRADATION OF DIESEL OIL IN SOIL AND ITS ENHANCEMENT BY APPLICATION OF BIOVENTING AND AMENDMENT WITH BREWERY WASTE EFFLUENTS AS BIOSTIMULATION-BIOAUGMENTATION AGENTS
}

\author{
Samuel Agarry', Ganiyu K. Latinwo' \\ 1 Ladoke Akintola University of Technology, Ogbomoso, Nigeria, e-mail: sam_agarry@yahoo.com; gklatinwo@ \\ lautech.edu.ng
}

Received: 2014.11.23

Accepted: 2015.02.04

Published: 2015.04.01

\begin{abstract}
The purpose of this study is to investigate and evaluate the effects of natural bioattenuation, bioventing, and brewery waste effluents amendment as biostimulation-bioaugmentation agent on biodegradation of diesel oil in unsaturated soil. A microcosm system was constructed consisting of five plastic buckets containing $1 \mathrm{~kg}$ of soil, artificially contaminated or spiked with $10 \% \mathrm{w} / \mathrm{w}$ of diesel oil. Biodegradation was monitored over 28 days by determining the total petroleum hydrocarbon content of the soil and total hydrocarbon degrading bacteria. The results showed that combination of brewery waste effluents amendment and bioventing technique was the most effective, reaching up to $91.5 \%$ of diesel removal from contaminated soil; with the brewery waste effluents amendment (biostimulation-bioaugmentation), the percentage of diesel oil removal was $78.7 \%$; with bioventing, diesel oil percentage degradation was $61.7 \%$ and the natural bioattenuation technique resulted in diesel oil removal percentage be not higher than $40 \%$. Also, the total hydrocarbon-degrading bacteria (THDB) count in all the treatments increased throughout the remediation period. The highest bacterial growth was observed for combined brewery waste effluents amendment with bioventing treatment strategy. A firstorder kinetic model was fitted to the biodegradation data to evaluate the biodegradation rate and the corresponding half-life time was estimated. The model revealed that diesel oil contaminated-soil microcosms under combined brewery waste effluents amendment with bioventing treatment strategy had higher biodegradation rate constants, $k$ as well as lower half-life times, $t_{1 / 2}$ than other remediation systems. This study showed that the microbial consortium, organic solids, nitrogen and phosphorus present in the brewery waste effluents proved to be efficient as potential biostimulation-bioaugmentation agents for bioremediation processes of soils contaminated with diesel oil.
\end{abstract}

Keywords: bioremediation, bioventing, biostimulation, bioaugmentation, brewery waste effluents, diesel oil, first-order kinetics.

\section{INTRODUCTION}

Petroleum-based products are the major source of energy for industry and daily life. Leakages and accidental spills occur regularly during the exploration, production, refining, transport, and storage of petroleum and petroleum products. The contamination of soil by crude oil and petroleum products has become a serious problem that represents a global concern for the potential consequences on ecosystem and human health
[Onwurah et al., 2007]. Among petroleum products, diesel oil is a complex mixture of alkanes and aromatic compounds that are frequently reported as soil contaminants leaking from storage tanks and pipelines or released in accidental spills [Gallego et al., 2001]. The scale of hazards imposed on the natural environment depends on the surface of the area contaminated by the petroleum products, their chemical composition, and the depth at which pollutants occur [Wolicka et al., 2009]. The technology commonly used for 
soil remediation includes mechanical, burying, evaporation, dispersion, and washing. However, these technologies are expensive and can lead to incomplete decomposition of contaminants [Das and Chandra, 2011]. For this reason an increasing attention has been directed toward the research of new strategies and environmental-friendly technologies to be applied for the remediation of soil contaminated by petroleum hydrocarbons. Among these, bioremediation technology which involves the use of microorganisms to detoxify or remove pollutants through the mechanisms of biodegradation has been found to be an environmentally-friendly, noninvasive and relatively cost-effective option [April et al., 2000].

The activation of natural degradation potentials in environmental media is currently the challenge in the environmental research addressed to remediation methods. Ways to activate these potentials must consider that most degradation potentials are widely distributed among microorganisms (Alexander, 1999) but indigenous microbes are usually present in a very small number. Moreover, the degradative metabolism towards specific pollutants needs often to be induced. Possible ways to overcome these limitations include changes of physicochemical parameters ( $\mathrm{pH}, \mathrm{T}$, electron donors or acceptor, etc.) as well as a "niche adjustment" by the inoculation of competent microorganisms into these systems (bioaugmentation). Thus, petroleum hydrocarbon bioremediation in soil can be promoted or activated through stimulation of the indigenous microbial population, by introducing nutrients and oxygen into the soil (biostimulation) [Seklemova et al., 2001] or through inoculation of an enriched microbial consortium into soil (bioaugmentation) [Richard and Vogel, 1999; Bento et al., 2005].

Recently, researchers have focused on the use of oxygen-release compounds (ORCs) and supply of air to promote the direct oxidation of pollutants and, at the same time, to increase aerobic microbial degradation [Tsai et al., 2009; Agarry et al., 2012; Zhang et al., 2014]. Injection of air through the method of bioventing is amongst the known bioremediation technologies for cleaning up the petroleum contaminated soil in the unsaturated zone. Bioventing has been defined as a method that stimulates indigenous microorganisms to biodegrade aerobically degradable compounds in soil by providing adequate oxygen or aeration [Leeson and Hinchee, 1997; Byun et al., 2006]. Biostimulation and bioaugmentation strategies has been widely used in remediation of organic contaminated soils in the past few years. Effective bioremediation of petroleum-contaminated soil using bioventing has been proved by some research [Moller et al., 1996; Kirsten et al., 2005; Byun et al., 2006; Morales et al., 2013; Thome et al., 2014].

Positive effects of nitrogen amendment using nitrogenous fertilizer on microbial activity and/ or petroleum hydrocarbon degradation have been widely demonstrated [Brook et al., 2001; Margesin et al., 2007]. However, in developing countries, inorganic chemical fertilizers are costly as well as not sufficient for agriculture, let alone for cleaning oil spills. Therefore, it necessitates the search for cheaper and environmentally friendly options of enhancing petroleum hydrocarbon degradation. One of such options is the use of organic wastes effluents that could act as bulking agents and also as bacterial biomass suppliers. There are no adequate literatures on the potential use of these industrial-derived organic wastes effluents as biostimulating and bioaugmentation agents. However, few workers have investigated the potential use of solid organic wastes such sugarcane bagasse [Molina-Barahona et al., 2004], spent brewery grain [Abioye et al., 2009] and animal wastes like cow dung [Akinde and Obire, 2008; Singh and Fulekar, 2009], pig dung [Yakubu, 2007], poultry manure [Okiemen and Okiemen, 2005], goat dung [Agarry et al., 2010], and sewage sludge [Mao and Yue, 2010] as biostimulating agents in the cleanup of soil contaminated with petroleum hydrocarbons and were found to show positive influence on petroleum hydrocarbon biodegradation in a polluted environment. Nevertheless, the search for cost effective and environmentally friendly methods of petroleum hydrocarbon removal from contaminated sites still needs to be further investigated. However, to the best of our knowledge, there is a dearth of information on the use of brewery waste effluents for stimulation of autochthonous microflora of petroleum hydrocarbons-contaminated soils. Furthermore, the evaluation and comparison of bioventing and liquid organic wastes in petroleum hydrocarbon bioremediation has not been reported in the literature.

Therefore, the objectives of this study are to determine the biostimulation-bioaugmentation potential of brewery waste effluents as either alone and/or in combination with bioventing in enhancing the biodegradation of diesel oil as the 
target contaminant in soil. Also, to evaluate and compare, model and analyzed the degradation kinetics of diesel oil for natural attenuation, bioventing, and organic wastes effluents enhanced bioremediation.

\section{MATERIALS AND METHODS}

\section{Sample collection}

The main materials used for this study are: soil, brewery waste effluents and diesel oil. Soil samples were collected from an un-impacted zone of Ladoke Akintola University of Technology Agricultural Farm. About $2 \mathrm{~kg}$ of bulk surface and subsurface soil was collected from different areas on the sampling sites. The bulked composite soil was preserved by putting them in sterile polyethylene bag, properly sealed and kept in the refrigerator prior to further use. The brewery waste effluents were collected from Nigerian Breweries Plc., Ibadan, Nigeria. The diesel oil was obtained from a commercial petroleum products station, Ogbomoso, Nigeria.

\section{Soil and brewery waste effluents characterisation}

The soil sample was characterized for total organic carbon (TOC), total nitrogen $(\mathrm{N})$, total phosphorus, moisture content, $\mathrm{pH}$, and total hydrocarbon degrading bacteria (THDB) according to standard methods. Soil $\mathrm{pH}$ was determined according to the modified method of McLean (1982); total organic carbon was determined by the modified wet combustion method [Nelson and Sommers, 1982] and total nitrogen was determined by the semi-micro-Kjeldahl method [Bremner and Mulvaney, 1982]. Available phosphorus was determined by Brays No. 1 method
[Olsen and Sommers, 1982] and moisture content was determined by the dry weight method. The total hydrocarbon degrading bacteria (THDB) populations were determined by the vapor phase transfer method [Amanchukwu et al., 1989]. The physic-chemical and microbiological properties of the soil and brewery waste effluents are given in Table 1.

As shown in Table 1, brewery waste effluents contained significantly large amount of effective nitrogen, effective phosphorus and microorganism compared with the soil having low level of total nitrogen and phosphorus suggesting low nutrient level. These analyses indicate that brewery waste effluents can be added as nourishment for composting of soil. Moreover, the addition of brewery waste effluents can increase the microorganism density and the activity of soil. Organic component in brewery effluent (expressed as COD) is generally and easily biodegradable as it mainly consists of sugar, soluble starch, ethanol, volatile fatty acids, while the brewery solids (expressed as TSS) mainly consist of spent grains, kieselguhr, waste yeast and ('hot') trub [Inyang et al., 2012].

\section{Isolation, Characterization, and Identification of Bacteria in Soil and Brewery waste effluents}

The spread plate technique [APHA, 2005] using nutrient agar (Oxoid) was employed for the isolation of bacteria in soil and brewery waste effluents. The plates were incubated at $37^{\circ} \mathrm{C}$ for 18 -24 h. Pure bacterial isolates were characterized and identified using various criteria, as described by Krieg et al. (1994). Bacteria and fungi isolated from brewery waste effluents include Pseudomonas sp, Acetobacter sp, and Flavobacterium sp, Aspergillus niger, Curvularia sp and Alternaria $\mathrm{sp}$, respectively. Meanwhile, the microorgan-

Table 1. Physical-chemical and microbiological characteristics of unimpacted soil and brewery waste effluents

\begin{tabular}{|l|c|c|}
\hline \multicolumn{1}{|c|}{ Parameters } & Soil & Brewery waste effluents \\
\hline Total nitrogen (\%) & $0.06 \pm 0.01$ & 0.34 \\
\hline Total carbon (\%) & $0.45 \pm 0.03$ & - \\
\hline Total organic matter (\%) & $0.78 \pm 0.02$ & 0.44 \\
\hline Available phosphorus (\%) & - & 30 \\
\hline Biochemical Oxygen Demand (BOD) mg/l & - & 410 \\
\hline Chemical Oxygen Demand (COD) mg/l & - & 65 \\
\hline Total Suspended Solids (TSS) mg/l & 7 & 8.2 \\
\hline pH & - & $0.2 \pm 5.0 \times 10^{10}$ \\
\hline Bacterial count (cfu/g) & $0.6 \times 10^{6}$. & \\
\hline
\end{tabular}


isms present in the LAUTECH agricultural soil were identified to be made up of mainly Bacillus and Pseudomonas species.

\section{Experimental design for the bioremediation of diesel oil-spiked soil}

Five plastic buckets used as bioreactors were prepared for each soil treatment, designated as bioattenuation (treatment A), bioventing (treatment B), brewery waste effluents amendment (treatment C), combined brewery waste effluents amendment and bioventing (treatment D), and control experiment (treatment E). Each bioreactor contained $1 \mathrm{~kg}$ of soil, spiked with $150 \mathrm{ml}$ of 100 $\mathrm{g}$ of diesel oil $(10 \% \mathrm{w} / \mathrm{w})$ and thoroughly mixed together to achieve complete artificial contamination. $10 \%$ spiking was adopted in order to achieve severe contamination as the concentration above $3 \%$, oil has been reported to be increasingly deleterious to soil biota and crop growth [Osuji et al., 2005]. Two weeks after the contamination (to allow for aging), the different remediation treatments were applied. For bioreactors B and D, air compressor pump used by vulcanizer was used to allow for atmospheric air to be drawn in towards a perforated pipe in the centre. The bioreactor under treatment $\mathrm{C}$ was amended with $50 \mathrm{~g}$ of brewery waste effluents and the bioreactor under treatment $\mathrm{D}$ was amended with $50 \mathrm{~g}$ of brewery waste effluents and subjected to bioventing. The bioreactor under treatment A was neither amended with brewery waste effluent nor subjected to bioventing. Soil in the bioreactor used as control experiment was sterilized three times by autoclaving at $121{ }^{\circ} \mathrm{C}$ for $15 \mathrm{~min}$. All the bioreactors with its contents were incubated at room temperature $\left(28 \pm 2{ }^{\circ} \mathrm{C}\right)$ for 28 days. Water content (moisture) of soil in each bioreactor was adjusted every week by addition of sterile de-ionized water to a moisture holding capacity of $50 \%$. In order to avoid anaerobic conditions, contents of the bioreactor were aerated by mixing every 3 days. Samples were taken every week and analyzed for total petroleum hydrocarbon (TPH) (i.e. residual diesel oil) and total hydrocarbon-degrading bacteria (THDB), respectively. The experiments were carried out in triplicates.

\section{Extraction and determination of total petroleum hydrocarbon}

The extent of hydrocarbon utilization in the diesel oil was estimated gravimetrically and spectrophotometrically [Adesodun and Mbagwu, 2008]. Soil samples (approximately $10 \mathrm{~g}$ ) was taken from each microcosm and put into a $50 \mathrm{~mL}$ flask and $20 \mathrm{~mL}$ of $\mathrm{n}$-hexane was added. The mixture was shaken vigorously on a magnetic stirrer for 30 minutes to allow the hexane extract the oil from the soil sample. The solution was then filtered using a Whatman filter paper and the liquid phase extract (filtrate) diluted by taking $1 \mathrm{~mL}$ of the extract into $50 \mathrm{~mL}$ of hexane. The absorbance of this solution was measured spectrophotometrically at a wavelength of $400 \mathrm{~nm} \mathrm{HACH}$ DR/2010 Spectrophotometer using n-hexane as blank. The total petroleum hydrocarbon in soil was estimated with reference to a standard curve derived from fresh crude oil of different concentration diluted with n-hexane. Percent degradation (D) was calculated using the following formula:

$$
\mathrm{D}=\frac{T P H_{i}-T P H_{r}}{T P H_{i}} \times 100
$$

Where $T P H_{i}$ and $T P H_{r}$ are the initial and residual $\mathrm{TPH}$ concentrations, respectively.

\section{Kinetic model analysis}

Kinetic analysis is a key factor for understanding biodegradation process, bioremediation speed measurement and development of efficient clean up for a petroleum hydrocarbon contaminated environment. The information on the kinetics of soil bioremediation is of great importance because it characterizes the concentration of the contaminant remaining at any time and permit prediction of the level likely to be present at some future time. Petroleum hydrocarbon biodegradation rates are usually difficult to predict due to the complexity of the environment [Zhu et al., 2001]. Nevertheless, biodegradation rate of organic compounds by microorganisms is often described by the equation as follows [Wang et al., 2001]:

$$
q=\frac{q_{m} c}{k+c}
$$

Where $q$ is biodegradation rate, $q_{m}$ is maximum specific biodegradation rate, $c$ is the substrate concentration and $k$ is half-saturation constant. If $c \leq k$; Eq. (2) can be reduced to:

$$
q=\frac{q_{m} c}{k}
$$

Eq. (3) is a typical first-order model. The use of first-order kinetics in the description of bio- 
degradation rates in environmental fate models is common because mathematically the expression can be easily incorporated into the model [Greene et al., 2000). Assuming $k_{1}=\left(q_{m} / k\right)$ and integrating Eq. (3), the following relation of substrate concentration to time can be obtained as given in Eq. (4):

$$
\ln c=a+k_{1} t
$$

\section{Estimation of biodegradation half-life times}

The biological half-life is the time taken for a substance to lose half of its amount. Biodegradation half-lives are needed for many applications such as chemical screening [Aronson et al., 2006], environmental fate modeling [Sinkkonen and Paasivirta, 2000] and describing the transformation of pollutants [Dimitrov et al., 2007; Matthies et al., 2008]. Biodegradation half-life times $\left(t_{1 / 2}\right)$ are calculated by Eq. (5) [Zahed et al., 2011; Agarry et al., 2013a]:

$$
t_{1 / 2}=\frac{\ln 2}{k}
$$

Where $k$ is the biodegradation rate constant $\left(\right.$ day $\left.^{-1}\right)$. The half-life model is based on the assumption that the biodegradation rate of hydrocarbons positively correlated with the hydrocarbon pool size in soil [Yeung et al., 1997].

\section{Data analysis}

The data were subjected to one-way analysis of variance (ANOVA) at 5\% probability. The data analysis was performed using statistical package for social sciences, version 16.0 (SPSS Inc., Chicago, IL, USA).

\section{RESULTS AND DISCUSSION}

\section{Diesel biodegradation}

The biodegradation profile of diesel oil in soil subjected to bioventing and also amended with brewery waste effluents is shown in Figure 1.

It is observed that the percentage reduction in TPH was relatively fast within the first 14 days of remediation in all the soil microcosms subjected to bioventing and that amended with brewery waste effluents and rapidly continued up to the fourth week (day 28) when compared to that of the unamended soil microcosm (natural bioattenuation). At the end of day 14, there was $17 \%, 27.7 \%$ and $36.2 \%$ TPH reduction in soil microcosms B, C and D subjected to bioventing, amended with brewery waste effluents, and combined brewery waste effluents + bioventing, respectively; while $10.6 \%$ TPH reduction occurred in the un-amended soil microcosm A (natural bioattenuation). At the end of remediation period (day 28), the concentration of diesel oil $(100,000 \mathrm{mg} / \mathrm{kg})$ was reduced to 38,300 , 21,300 , and $8,500 \mathrm{mg} / \mathrm{kg}$ and correspondingly $61.7 \%, 78.7 \%$, and $91.5 \% \mathrm{TPH}$ reduction was achieved under bioventing, brewery waste effluents amendment (biostimulation-bioaugmentation), and brewery waste effluents amendment combined with bioventing (biostimulation-bioaugmentation + bioventing) treatments, respectively. This observation revealed that during the diesel oil biodegradation in soil, bioventing and amendment with brewery waste effluents individually resulted in a more effective bioremediation response than the natural bioattenuation.

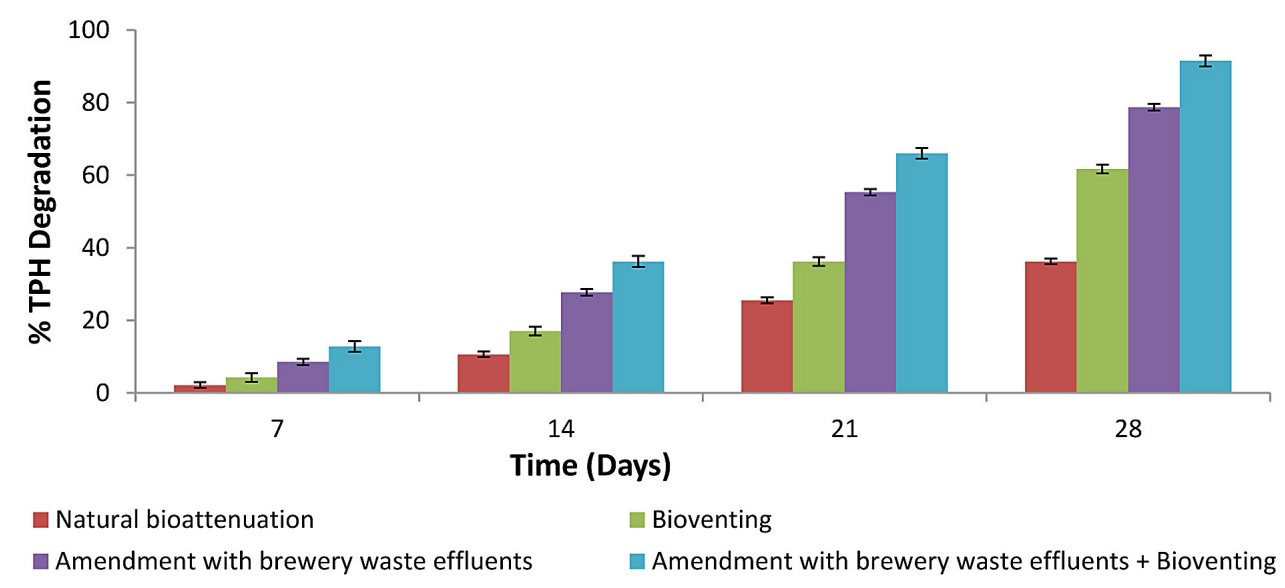

Figure 1. Time course for the biodegradation of diesel oil under natural bioattenuation, bioventing, brewery waste effluents amendment and combined brewery waste effluents amendment with bioventing. Bars indicate the average of triplicate samples while the error bars show the standard deviation 
These observations may be due to the fact that bioventing increased the oxygen level in the soil required by the autochthonous microorganisms while the brewery waste effluents increased the nutrients level as well as the microbial load or density in the soil thus acting as biostimulation and bioaugmentation agent. Similar observations have been reported using bioventing technique [Morales et al., 2013; Thomé et al., 2014] as well as using mixture of cow, goat and poultry dungs (which acts as biostimulation-bioaugmentation agent) [Agarry and Jimoda, 2013b], and brewery spent grain [Abioye et al., 2012] Nevertheless, amendment with brewery waste effluents elicited a higher biodegradation of diesel oil than the bioventing treatment. However, Morales et al. (2013) reported that that bioventing strategy enhanced the bioremediation of diesel oil more than bioaugmentation. Generally, in this work, the combination of brewery waste effluents amendment and bioventing (biostimulation-bioaugmentation + bioventing) treatment strategy showed relatively greater \%TPH degradation than the bioventing and brewery waste effluents amendment treatments respectively used alone during the whole period of remediation. Moller et al. (1996) and Thome et al. (2014) have respectively reported that biostimulation-bioventing elicited higher diesel oil biodegradation than biostimulation and bioventing respectively used alone.

Figure 2 shows the growth profiles of the total hydrocarbon degrading bacteria (THDB) in microcosms due to natural attenuation, bioventing, and brewery waste effluents amendments treatment methods.
Generally, it is seen that the microbial (THDB) counts increased from day 0 to day 28 in each of the treatment microcosms. For natural attenuation (microcosm A), the THDB count increased from $0.2 \pm 1.00$ to $0.1 \pm 2.54 \times 10^{10}$ cfu- $^{-1}$, while it increased from $0.3 \pm 1.10$ to $0.2 \pm$ $4.10 \times 10^{10} \mathrm{cfu}^{-1}, 0.1 \pm 1.08$ to $0.2 \pm 6.80 \times 10^{10}$ cfu- $^{-1}$, and $0.3 \pm 1.20$ to $0.2 \pm 9.80 \times 10^{10}$ cfu$\mathrm{g}^{-1}$ for bioventing (microcosm B), brewery waste effluents amendment (microcosm C), and brewery waste effluents amendment with bioventing (microcosm D), respectively. This corresponded to a growth increase of $364 \%, 530 \%$, and $717 \%$ for soil microcosms B, C and D subjected to bioventing, brewery waste effluents amendments and brewery waste effluents amendment with bioventing, respectively. The percentage THDB growth in the unamended soil (natural attenuation) is $154 \%$. This showed that the soil microcosms subjected to bioventing, brewery waste effluents amendments and brewery waste effluents amendment with bioventing enhanced the microbial growth rate which accounted for the higher microbial counts observed in all the soil microcosms subjected to bioventing and brewery waste effluents amendments either alone or in combination than the unamended soil microcosm (natural attenuation). The higher microbial count in soil microcosms subjected to bioventing and brewery waste effluents amendments either alone or in combination may be due to increased oxygen level and high nutrient level which stimulated increase in microbial population and activities thus leading to high energy (carbon) demand by the oil-degrading microbes.

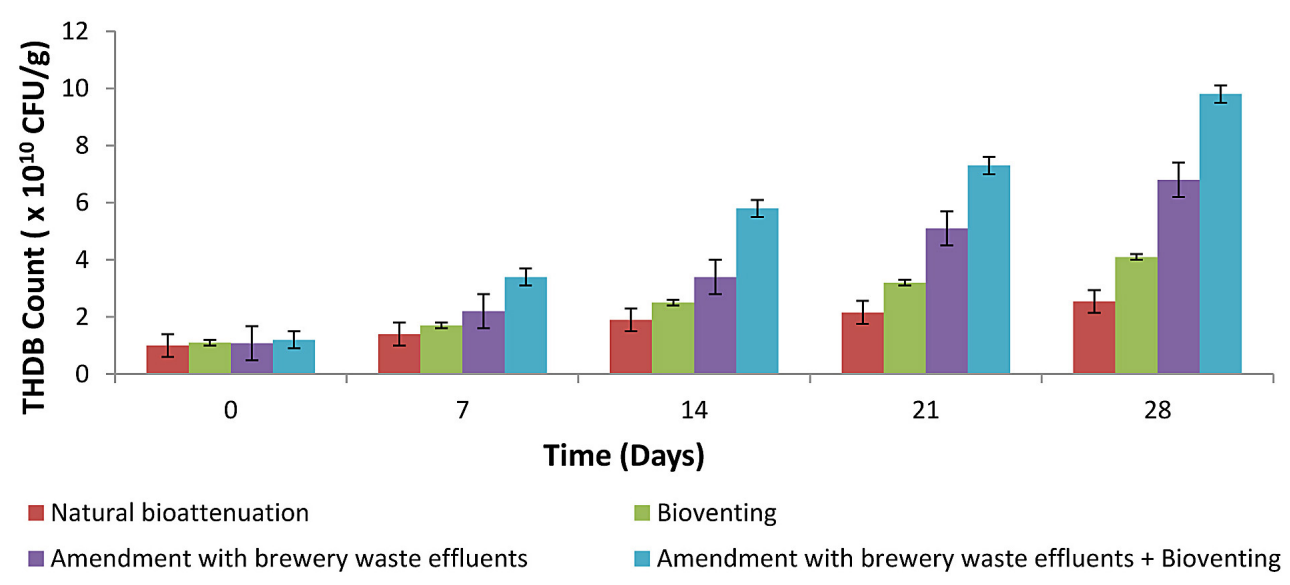

Figure 2. Time course for the growth of total hydrocarbon degrading bacteria (THDB) in diesel oil contaminated soil under natural bioattenuation, bioventing, brewery waste effluents amendment and combined brewery waste effluents amendment with bioventing treatments. Bars indicate the average of triplicate samples while the error bars show the standard deviation 


\section{Evaluation of Biodegradation Kinetics and Half-Life}

First-order kinetic model equation (Eq. 4) fitted to the biodegradation data was used to determine the rate of biodegradation of diesel oil in the various remediation treatments which is illustrated in Figure 3.

The biodegradation data fitted well to the first-order kinetic model with high correlation coefficient $\left(R^{2}\right)$ that lies between 0.90 and 0.98 . The half-life times of diesel oil biodegradation was calculated using Eq. 5. The biodegradation rate constants $(k)$ and half-life times $\left(t_{1 / 2}\right)$ for the different remediation treatments are presented in Table 2.

It is to be noted that the higher biodegradation rate constants, the higher or faster is the rate of biodegradation and consequently the lower is the half-life times. Table 2 shows

(a) Natural bioattenuation

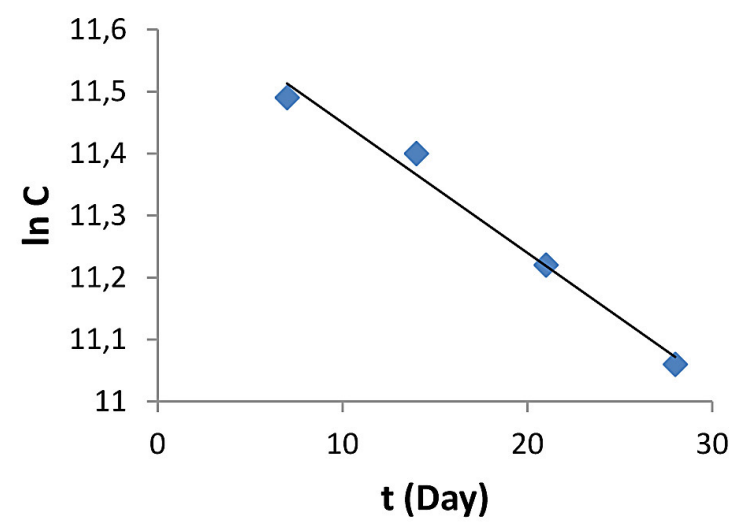

(c) Brewery waste effluents amendment

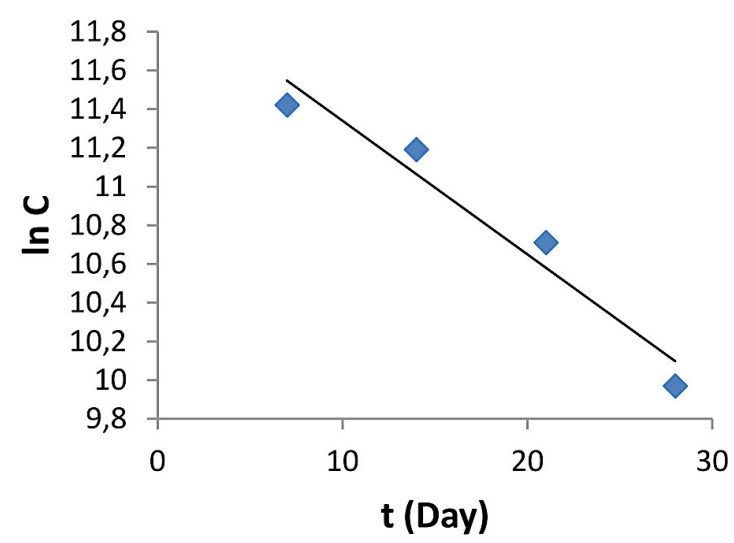

that the biodegradation of diesel oil in soil under combined brewery waste effluents amendments and bioventing treatment strategy had a higher $k\left(0.108\right.$ day $\left.^{-1}\right)$ and lower $t_{1 / 2}(6.4$ days) than that under brewery waste effluents amendment alone $\left(k=0.069\right.$ day $^{-1}$ and $t_{1 / 2}=10$ days), bioventing ( $k=0.043$ day $^{-1}$ and $t_{1 / 2}=16.1$ days), and natural attenuation $\left(k=0.016\right.$ day $^{-1}$ and $t_{1 / 2}=43.3$ days), respectively. Therefore, the value of the kinetic parameter showed that the degree of effectiveness of these treatment strategies in the clean-up of soil contaminated with diesel oil is in the following order: brewery waste effluents amendment with bioventing $>$ brewery waste effluents amendment $>$ bioventing $>$ natural bioattenuation. Nevertheless, these observations indicate that bioventing and brewery waste effluents amendment alone or in combinations enhanced TPH reduction. (b) Bioventing

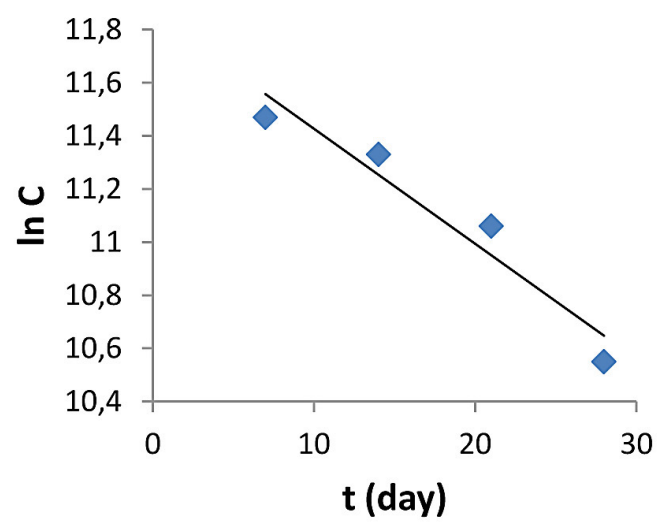

(d) Brewey waste effluents amendment with bioventing

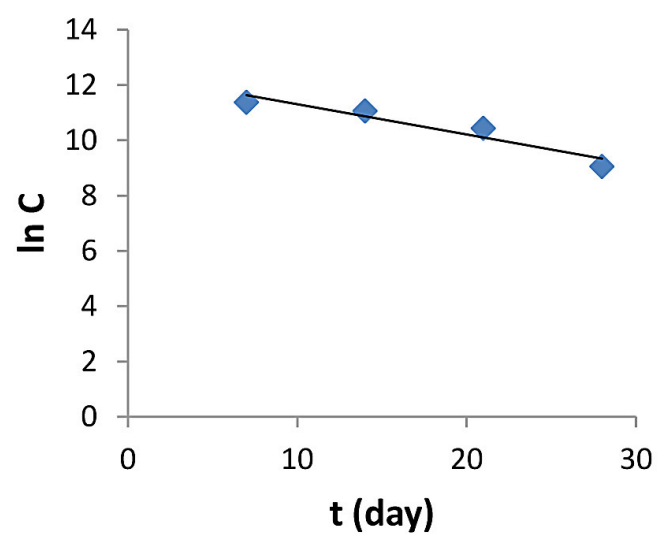

Figure 3. First-order kinetic model fitted to the diesel oil biodegradation data under (a) natural bioattenuation, (b) bioventing, (c) brewery waste effluents amendment, and (d) combined brewery waste effluents amendment with bioventing treatments 
Table 2. The biodegradation rate constants $(k)$ and half-life $\left(t_{1 / 2}\right)$ time of diesel biodegradation in the various treatments

\begin{tabular}{|c|l|c|c|c|}
\hline Microcosm code & \multicolumn{1}{|c|}{ Soil treatment } & $k\left(\right.$ day $\left.^{-1}\right)$ & $R^{2}$ & $t_{1 / 2}$ (days) \\
\hline A & Natural bioattenuation & 0.016 & 0.983 & 43.3 \\
\hline B & Bioventing & 0.043 & 0.929 & 16.1 \\
\hline C & Amendment with brewery waste effluents & 0.069 & 0.947 & 10 \\
\hline D & Amendment with brewery waste effluents + Bioventing & 0.108 & 0.909 & 6.4 \\
\hline
\end{tabular}

\section{CONCLUSIONS}

From this present study, it can be concluded that the reduction of diesel oil in the contaminated soil indicates the presence of diesel-degrading microbial communities; and that the rate of diesel oil biodegradation in soil could be enhanced by bioventing and amendment with organic waste effluents that could serve as both biostimulation and bioaugmentation agents, respectively. The soil treatment under combined brewery waste effluents amendments and bioventing exhibited the highest degree of biodegradation with the highest biodegradation rate constant $\left(k=0.108\right.$ day $\left.^{-1}\right)$ and lowest half-life time $\left(t_{1 / 2}=6.4\right.$ days $\left.)\right)$ and the soil treatment under natural bioattenuation the least degradation with the lowest biodegradation rate constant $\left(k=0.016\right.$ day $\left.^{-1}\right)$ and highest half-life time $\left(t_{1 / 2}=43.3\right.$ days $)$. Thus, the use of bioventing and biostimulation/bioaugmentation to enhance diesel oil biodegradation in the soil could be one of the severally sought bioremediation strategies of remediating natural ecosystem (environment) contaminated with petroleum hydrocarbons.

\section{REFERENCES}

1. Abioye P.O, Abdul Aziz A. and Agamuthu P. 2009. Enhanced biodegradation of used engine oil in soil amended with organic wastes. Water Air Soil Poll., 173-179.

2. Adesodun J.K. and Mbagwu J.S.C. 2008. Biodegradation of waste-lubricating petroleum oil in a tropical alfisol as mediated by animal droppings. Bioresource Technol., 99 (13), 5659-5665.

3. Agarry S.E., Owabor C.N., Yusuf R.O. 2012. Enhanced bioremediation of soil artificially contaminated with kerosene: Optimization of biostimulation agents through statistical experimental design. J. Pet. Environ. Biotechnol. 3, 120.

4. Agarry S.E., Aremu M.O., Aworanti O.A. 2013a. Kinetic modelling and half-life study on bioremediation of soil co-contaminated with lubricating motor oil and lead using different bioremediation strategies. Soil and Sediment Contam. An Int. J. 22 (7), 800-816.

5. Agarry S.E. and Jimoda L.A. 2013b. Application of Carbon-Nitrogen Supplementation from Plant and Animal Sources in In-situ Soil Bioremediation of Diesel Oil: Experimental Analysis and Kinetic Modelling.

6. Agarry S.E., Owabor C.N. and Yusuf R.O. 2010. Bioremediation of soil artificially contaminated with petroleum hydrocarbon mixtures: Evaluation of the use of animal manure and chemical fertilizer. Bioremediation J., 14 (4), 189-195.

7. Akinde S.B. and Obire O. 2008. Aerobic heterotrophic bacteria and petroleum-utilizing bacteria from cow dung and poultry manure. World J. Microbiol. Biotechnol., 24, 1999-2002.

8. Amanchukwu C.C., Obafemi A., Okpokwasili G.C. 1989. Hydrocarbon degradation and utilization by a palmwine yeast isolate. FEMS Microbiol. Lett. 57, 51-54.

9. APHA 1985. Standard Methods for Examination of water and wastewater. American Public Health Association Washington DC.

10. April T.M., Foght J.M. and Currah R.S. 2000. Hydrocarbon degrading filamentous fungi isolated from flare pit soils in northern and western Canada. Canadian J. Microbiol., 46 (1), 38-49.

11. Aronson D., Boethling R., Howard P., Stiteler W. 2006. Estimating biodegradation half-lives for use in chemical screening. Chemosphere 63, 1953-1960.

12. Bento F.M., Camargo F.A., Okeke B., Frankenberger Jr. T.W. 2003. Bioremediation of soil contaminated by diesel oil. Braz. J. Microbiol. 34 (Suppl. 1), 65-68.

13. Bremner J.M., Mulvaney C.S. 1982. Total nitrogen determination. In Method of Soil Analysis, vol. 2, ed. A.L. Page, R.H. Miller, and D.R. Keeney, pp. 595. Madison, WI: American Society of Agronomy.

14. Brook T.R., Stiver W.H., and Zytner R.G. 2001. Biodegradation of diesel fuel in soil under various nitrogen addition regimes. Soil Sediment Contamination 10, 539-553.

15. Das N. and Chandran P. 2011. Microbial degradation of petroleum hydrocarbon contaminants: an overview. Biotechnol. Res. Int., 1-13. 
16. Dimitrov S., Pavlov T., Nedelcheva D., Reuschenbach P., Silvani M. et al. 2007. A kinetic model for predicting biodegradation. SAR QSAR Environ. Res. 18, 443-457.

17. Gallego J.R., Loredo J., Llamas J.F., Vazquez F. and Sanchez J. 2001. Bioremediation of dieselcontaminated soils: evaluation of potential in situ techniques by study of bacterial degradation. Biodegradation, 12, 325-335.

18. Greene E.A., Kay J.G., Jaber K., Stehmeier L.G., Voordouw G. 2000. Composition of soil microbial communities enriched on a mixture of aromatic hydrocarbons. Appl. Environ. Microbiol. 66, 5282-5289.

19. Inyang U.E., Bassey E.N., and Inyang J.D. 2012. Characterization of brewery effluent fluid. J. Eng. Appl. Sci. 4, 67-77.

20. Kirsten S., Hung L., Zytner R.G. 2005. Optimization of nitrogen for bioventing of gasoline contaminated soil. J. Environ. Eng. Sci. 4 (1), 29.

21. Krieg N.R., Holt J.G., Sneath P.H.A., Stanley J. T. and Williams S.T. 1994. Bergey's Manual of Determinative Bacteriology, 9th ed., Williams and Wilkins, Baltimore.

22.Lee T.H., Byun I.G., Kim Y.O., Hwang I.S., Park T.J. 2006. Monitoring biodegradation of diesel fuel in bioventing processes using in situ respiration rate. Water Science \& Technology, $53(4 / 5), 263$

23. Mao L. and Yue Q. 2010. Remediation of dieselcontaminated soil by bioventing and composting technology. International Conference on Challenges in Environmental Science and Computer Engineering, pp. 3-6.

24. Margesin R., Hammerle M. and Tscherko D. 2007. Microbial activity and community composition during bioremediation of diesel-oil-contaminated soil: Effects of hydrocarbon concentration, fertilizers, and incubation time. Microbiol Ecol., 53, 259-269.

25. Matthies M., Witt J., Klasmeier J. 2008. Determination of soil biodegradation half lives from simulation testing under aerobic laboratory conditions: a kinetic model approach. Environ. Poll. 156, 99-105.

26. McLean E.O. 1982. Soil $\mathrm{pH}$ and lime requirement in methods in soil analysis: Chemical and microbiological properties. Part II, ed. C.A. Black. Madison, WI: American Society of Agronomy.

27. Molina-Barahona L., Rodriguez-Vázquez R., Hernández-Velasco M., Vega-Jarquin C., ZapataPérez O., Mendoza-Cantú A. and Albores A. 2004. Diesel removal from contaminated soils by biostimulation and supplementation with crop residues. Appl. Soil Ecol., 27, 165-175.
28. Møller J., Winther P., Lund B., Kirkebjerg K., and Westermann P. 1996. Bioventing of diesel oil-contaminated soil: Comparison of degradation rates in soil based on actual oil concentration and on respirometric data. J. Ind. Microbiol. 16 (2), 110-116.

29. Morales M., Maria A., Munoz S., Claudia Quintero P., Silvia L. 2013. Evaluation of natural attenuation, bioventing, bioaugmentation and bioaugmentationbioventing techniques, for the biodegradation of diesel in a sandy soil, through column experiments. Gestion y Ambiente, 16(2), 83-94.

30. Nelson D.W., Sommers L.E. 1982. Determination of organic carbon. [In:] Method of Soil Analysis, vol. 2, ed. A.L. Page, R.H. Miller, and D.R. Keeney, 539. Madison, WI: American Society of Agronomy.

31. Okiemen C.O. and Okiemen F.E. 2005. Bioremediation of crude oil polluted soil. Effect of poutry droppings and natural rubber processing sludge application on biodegradation of petroleum hydrocarbon. Environ. Sci. 1(1), 1-8.

32. Olsen S.R., Sommers L.E. 1982. Determination of available phosphorus. [In:] Method of Soil Analysis, vol. 2, ed. A.L. Page, R H. Miller, and D.R. Keeney, 403. Madison, WI: American Society of Agronomy.

33. Onwurah I.N.E., Ogugua V.N., Onyike N.B., Ochonogor A.E. and Otitoju O.F. 2007. Crude oil spills in the environment, effects and some innovative clean-up biotechnologies. Int. J. Environ. Res., 1, 307-320.

34. Osuji L.C., Egbuson E.J.G. and Ojinnaka C.M. 2005. Chemical reclamation of crude-oil-inundated soils from Niger Delta. Nigeria. Chem. Ecol., 21(1), 1-10.

35. Richard J.Y. and Vogel T.M. 1999. Characterization of a soil bacterial consortium capable of degrading diesel fuel. Int. Biodeter. Biodegrad., 44, 93-100.

36. Seklemova E., Pavlova A. and Kovacheva K. 2001. Biostimulation based bioremediation of diesel fuel: field demonstration. Biodegradation, 12, 311-316.

37. Singh D. and Fulekar M.H. 2009. Bioremediation of benzene, toluene and o-xylene by cow dung microbial consortium. JABs 14, 788-795.

38. Sinkkonen S., Paasivirta J. 2000. Degradation half-life times of PCDDs, PCDF sand PCBs for environmental fate modeling. Chemosphere 40, 943-949.

39. Thomé A., Reginatto C., Cecchin I. and Colla L. 2014. Bioventing in a Residual Clayey Soil Contaminated with a Blend of Biodiesel and Diesel Oil. J. Environ. Eng., 10.1061/(ASCE)EE.1943$7870.0000863,06014005$. 
40. Tsai T.T., Kao C.M., Surampalli R.Y., Chien H.Y. 2009. Enhanced Bioremediation of Fuel-Oil Contaminated Soils: Laboratory Feasibility Study. J. Environ. Eng. 135, 845-853.

41. Wang J.L., L.P. Han, H.C. Shi, and Y. Qian 2001. Biodegradation of quinoline by gel immobilized Burkholderia sp. Chemosphere 44, 1041-1046.

42. Wolicka D., Suszek A., Borkowski A. and Bielecka A. 2009. Application of aerobic microorganisms in bioremediation in situ of soil contaminated by petroleum products. Bioresour. Technol., 100, 3221-3227.

43. Yakubu M.B. 2007. Biodegradation of Lagoma crude oil using pig dung. Afri. J. Biotechnol., 6, 2821-2825.

44. Yeung P.Y., Johnson R.L., Xu J.G. 1997. Biodegradation of petroleum hydrocarbons in soil as affected by heating and forced aeration. J. Environ. Quality 26, 1511-1576.
45. Zahed M.A., Abdul Aziz H., Isa M.H., Mohajeri L., Mohajeri S., Kutty S.R.M. 2011. Kinetic modeling and half life study on bioremediation of crude oil dispersed by Corexit 9500. J. Hazard Mater. 185, 1027-1031.

46. Zhang S., Wang X., Zhu R., Li H., Wang P., Yang J., Lin K., Gu J., and Liu Y. 2014. Aerobic biodegradation of trichloroethylene by a bacterial community that uses hydrogen peroxide as sole oxygen source. http://www.paper.edu.cn/download/downpaper/201406-149.

47. Zhu X, Venosa A.D., Suidan M.T., Lee K. 2001. Guidelines for the Bioremediation of Marine Shorelines and Freshwaters Waterlands. US Environmental Protection Agency Office of Research and Development National Risk Management Research Laboratory. 